\title{
Student's thinking path in mathematics problem-solving referring to the construction of reflective abstraction
}

\author{
Patma Sopamena $^{1}$, Toto Nusantara, Eddy Bambang Irawan, Sisworo ${ }^{2}$, Kamirsyah Wahyu ${ }^{3}$
}

\begin{abstract}
Abstrak: Artikel ini merupakan bagian dari penelitian yang bertujuan mengungkap jalur berpikir mahasiswa dalam menyelesaikan masalah matematika berdasarkan konstruksi abstraksi reflektif. Abstraksi reflektif merupakan proses berpikir individu dalam membangun struktur logika (struktur matematis logis) melalui interiorisasi, koordinasi, enkapsulasi, dan generalisasi. Artikel ini akan menganalisis seorang mahasiswa yang memiliki jalur berpikir tertutup sederhan, salah satu dari dua jalur berpikir yang terungkap dalam penelitian, dalam menyelesaikan permasalahan limit. Proses berpikir mahasiswa dalam menyelesaikan masalah matematika berdasarkan konstruksi abstraksi reflektif dapat terjadi melalui jalur interiorisasi - koordinasi - enkapsulasi - generalisasi kemudian ke koordinasi - enkapsulasi - generalisasi. Hasil penelitian ini memberikan alternatif dalam memahami dan merancang aktivitas pemecahan masalah dalam pembelajaran matematika.
\end{abstract}

Kata kunci: Jalur berpikir, Masalah limit, Abstraksi reflektif, Jalur tertutup sederhana

Abstract: This article is a part of research which aimed to reveal the path of undergraduate students' thinking in solving mathematical problems referring to the construction of reflective abstraction. Reflective abstraction is the process of thinking in constructing logical structures (logicomathematical structures) by individuals through interiorization, coordination, encapsulation, and generalization. This article seeks to analyze a student with the simple closed path, as one of the two types of students' thinking path found in the research, in solving limit problems. The thinking process of the student in solving mathematical problems occurred through the path of interiorization coordination - encapsulation - generalization then to coordination - encapsulation - generalization. The path of student's thinking yields alternative to understand and marshal problem-solving activities in mathematics learning.

Keywords: Thinking path, Limit problem, Reflective abstraction, Simple closed path

\section{A. Introduction}

Hershkowitz, Schwarz, and Dreyfus (2001) defined abstraction as a vertical reorganization activity of mathematical concepts that have been constructed previously through a new mathematical structure. New mathematical objects are constructed through the establishment of such relationships to find new generalizations, evidence, or strategies on problem-solving. Piaget (2001) distinguishes three kinds of abstractions namely empirical abstraction, pseudo-empirical abstraction, and reflective abstraction.

Beth and Piaget (1966) asserted that empirical abstraction is a knowledge derived from the properties of objects. It means that knowledge can be gained from experiences that arise. This

\footnotetext{
${ }^{1}$ Islamic Institute State of Ambon, Maluku, Indonesia, patma.sopamena@iainambon.ac.id

2 State University of Malang, Indonesia

${ }^{3}$ Universitas Islam Negeri Mataram, Indonesia.
} 
type of abstraction results from the decrease in the general properties of an object and the extension of a generalization, meaning that they are explained from the particular to the general (Piaget, 2001). Pseudo-empirical abstraction is the midway between an empirical abstraction and a reflective abstraction and separates these two properties so that the action of the subject is introduced as an object. The reflective abstraction is illustrated by Piaget (2001) as general coordination of action so that the source is a subject equipped with complete internal properties. The same idea was also conveyed by Dubinsky (1991), Campbell (2001), Cooley (2002) and Tall (2013) that reflective abstraction is a mechanism for isolating specific properties of mathematical structures. For example, a child who forms individual actions to form pairs of two, three, etc. This type of abstraction produces a sequence that is very different about something in general where it is constructive and produces "a new synthesis that gives rise to a new meaning." Empirical abstractions and pseudo-empirical abstractions represent the knowledge of objects by displaying or imagining action on them. The reflective abstraction interprets and coordinates these actions to form new actions, and produces new objects that are no longer physically shaped but instead lead to their mathematical concepts such as functions and groups. Empirical abstraction then extracts data from the new objects through mental action on it, and so on.

Piaget believes that reflective abstraction is essential for higher mathematical logic thinking as occurs in logical thinking in children. Therefore, to develop a reflective abstraction notion of high-level mathematical thinking, it is necessary to separate what is an essential feature of reflective abstraction, reflect its rules on higher mathematics, recognize and reconstruct it so that a similar theory of knowledge can establish mathematics and its instructions (Tall, 2013). Furthermore, Dubinsky (1991) explain that reflective abstraction is a concept introduced by Piaget to describe the construction of an individual's mathematical logic structure in cognitive development when studying a concept.

Many researchers and theorists have recognized reflective abstractions as an important focus for educators. Steffe (1991) considers "reflective abstraction to be very useful as a guiding heuristic in the quest to understand learning mathematics...(p. 43)." The reflective abstraction according to Thompson (2000) is central to the use of didactical objects. Gallagher and Reid (1981) suggest that finding ways to facilitate reflexive abstraction is the key to promoting growth. Dubinsky (1991) asserts that "... when well understood, reflective abstractions appear as a description of the mechanisms of intellectual thought development...(p. 102)".

Piaget distinguishes reflective abstractions in four types of construction processes: interiorization, coordination or composition, encapsulation or conversion, and generalization (Paschos \& Farmaki, 2006). They explain each of the processes as follows. Interiorization is an internal process which makes meanings of the perceived phenomena. Coordination or composition is a composition of two or more processes for the construction of a new one. Encapsulation or conversion is the conversion of a (dynamic) process into a (static) object. When a subject learns to apply an existing schema to a broader collection of phenomena, then the schema has been generalized. Generalization can also happen when a process is encapsulated to an object (Paschos \& Farmaki, 2006). Furthermore, since these types of constructions of reflective abstractions are also processes, they can be formed as a path of construction through which they think when solving mathematics problems. The construction path in the research is called the thinking path. We define thinking path as the path the undergraduate student pass through, namely interiorization, coordination, encapsulation, and generalization in solving a limit problem. 
Some prior researches on this topic (e.g., Capetta, 2007) have shown the occurrence of types of the construction of reflective abstraction which begin with interiorization and end with generalization. However, the researches had not focused on a possible path of construction the students go through. Ayers, Davis, and Lewin (1988) investigated how students solve composition of function which refers to reflective abstraction. The found that: (1) the constructions in reflective abstraction are not automatic, (2) the use of the computer in teaching abstract concepts could provide concrete experiences and trigger reflective abstraction, (3) the use of a computer is more effective in creating reflective abstraction than traditional learning. Paschos and Farmaki (2006) conducted a case study which involves one undergraduate student. The subject solved finite integral then was interviewed. They found the construction of reflective abstraction emerged in the subject, i.e., interiorization, coordination, encapsulation, reversal, and generalization. Capetta (2007) designed learning in control and experiment group which aimed to reveal the emergence of reflective abstraction on the students. It was found that in both groups, some students had complete construction of reflective abstraction (five constructions) and some were not complete.

The prior researches (e.g., Ayers, Davis \& Lewin, 1988; Paschos \& Farmaki, 2006; Capetta, 2007) have not focused on the thinking path of students in solving mathematics problems which refer to reflective abstraction or just studied the types of the construction of reflective abstraction. In this case, the research we conducted aimed to reveal the path of students' thinking in solving mathematical problems referring to the construction of reflective abstraction. The research extended our understanding not only to the emergence and types of the constructions but also the path of students' thinking in the construction.

\section{B. Methods}

The research was qualitative-explorative research since we explored the path of students' thinking referring to the construction of reflective abstraction. The exploration aimed to provide thorough explanations of the constructions that have not been previously focussed (Reiter, 2017; Stebbins, 2008). Snowball method was used to select the subjects. The undergraduate students were given a mathematics problem. They solved the following problem and expressed loudly what they were thinking of the problem (Think out loud). The selected students had enrolled in Calculus and Real Analysis course. The communication ability of the students was also considered since they required to express their thinking verbally.

Given $f(x)= \begin{cases}2 x & x<2 \\ 5 & x=2 \\ -2 x+8 & x>2\end{cases}$

a. Investigate if $\lim _{x \rightarrow 2} f(x)$ exist! Determine its value!

b. If it exists, prove it with formal definition!

After solving the problem, we checked their answers. If the answer was incorrect, then we gave them some minutes to reflect. If after the reflection the students could not revise their answers then the students were not selected as the subjects. Otherwise, if they could revise their answers, then they were selected as the subjects. This process was repeated until we achieved answers to the research question and the data got saturated level. The number of selected subjects was adjusted to the saturated data, and the research questions were answered. Thus, we had 
fourteen subjects which have the path of thinking based on reflective abstraction. The nine subjects had a not-simple closed path, and the other five were a simple closed path. One of the five subjects who had simple closed path is analyzed in this article. We code the one subject in this article as S1.

We developed the framework (Table 1) to ease the analysis of students' thinking path in solving the limit problem referring to the four constructions of reflective abstraction.

Table 1. The description of the construction of reflective abstraction

\begin{tabular}{|c|c|}
\hline The components & Operational description \\
\hline Interiorization & $\begin{array}{l}\text { 1. Read the limit problem } \\
\text { 2. Observe the form of function } \\
\text { 3. Identify the function } \\
\text { 4. Substitute the values of } x \text { to } x \text { approaches } 2 \text { for the estimation } \\
\text { of } \lim _{x \rightarrow 2^{-}} 2 x \\
\text { 5. Substitute the values of } x \text { to } x \text { approaches } 2 \text { for the estimation } \\
\text { of } \lim _{x \rightarrow 2^{+}}-2 x+8\end{array}$ \\
\hline Coordination & $\begin{array}{l}\text { 1. Coordinate the process of substituting the values of } x \text { approach } 2 \\
\text { for the estimation of } \lim _{x \rightarrow 2^{+}} 2 x \text { using a graph, table, or algebra } \\
\text { 2. Coordinate the process of substituting the values of } x \text { approach } 2 \\
\text { for the estimation of } \lim _{x \rightarrow 2^{+}}-2 x+8 \text { using a graph, table, or } \\
\text { algebra } \\
\text { 3. Coordinate } \lim _{x \rightarrow 2^{+}} 2 x \text { and } \lim _{x \rightarrow 2^{+}}-2 x+8 \text { to determine } \lim _{x \rightarrow 2} f(x) \\
\text { 4. Coordinate } \varepsilon \text { and } \delta \text { to determine } \delta \text { using algebra manipulation } \\
\text { 5. Coordinate the value of } \delta=\frac{\varepsilon}{2} \text { to define left-limit }\end{array}$ \\
\hline Encapsulation & $\begin{array}{l}\text { 1. Determine } \lim _{x \rightarrow 2^{+}} 2 x=4 \text { and } \lim _{x \rightarrow 2^{+}}-2 x+8=4 \\
\text { 2. Determine the existence of } \lim _{x \rightarrow 2} f(x) \text { based on the coordination of } \\
\lim _{x \rightarrow 2^{+}} 2 x=4 \text { with } \lim _{x \rightarrow 2^{+}}-2 x+8=4 \\
\text { 3. Determine } \lim _{x \rightarrow 2} f(x)=4 \\
\text { 4. Determine the value of } \delta=\frac{\varepsilon}{2} \\
\text { 5. Construct the definition of } \lim _{x \rightarrow 2^{+}} 2 x=4 \text { relying on the } \\
\text { coordination of relation of } \text { and } \delta \text { through algebra manipulation } \\
\text { 6. Construct the definition of } \lim _{x \rightarrow 2^{+}}-2 x+8=4 \text { relying on the } \\
\text { coordination of relation of } \varepsilon \text { and } \delta \text { through algebra manipulation }\end{array}$ \\
\hline $\begin{array}{l}\text { Generalization or } \\
\text { Generalized }\end{array}$ & $\begin{array}{l}\text { 1. Use the definition of left-limit to prove } \lim _{x \rightarrow 2^{+}} 2 x=4 \\
\text { 2. Use the definition of right-limit to prove } \lim _{x \rightarrow 2^{+}}-2 x+8=4 \\
\text { 3. Use the relation between } \varepsilon \text { and } \delta=\frac{\varepsilon}{2} \text { to prove } \lim _{x \rightarrow 2^{+}} 2 x=4 \\
\text { 4. Use the relation between } \varepsilon \text { and } \delta=\frac{\varepsilon}{2} \text { to prove } \lim _{x \rightarrow 2^{+}}-2 x+8=4\end{array}$ \\
\hline
\end{tabular}

The process of data analysis in the research was carried out by (1) transcribing verbal data (results of think aloud, interviews, observations, field notes, and results of construction of student mathematical concepts), (2) conducting data reduction (coding, drawing thinking structures), (3) analyzing thought processes, and (4) drawing conclusions (Creswell, 2012). 


\section{Findings and Discussion}

In solving the limit problem, the fourteen subjects firstly constructed internal process (a process of interiorization) from given information on the problem. The process was then continued with the coordination in which the subjects coordinate several processes from both interiorization and encapsulation into new processes. Further process of the coordination was continued by concluding or assigning mathematical objects from the coordination dynamically. Eventually, the subjects generalized by applying the process of encapsulation to the next process (Sopamena, Nusantara, Irawan, \& Sisworo, 2016).

When S1 solves the problem, the structure of his thinking is incomplete. It is indicated by the missing of several substructures as the crucial components in solving problems (unilateral limits, unilateral limit rules, and unilateral limit definitions). Although in the process of solving the problem S1 makes a mistake, after being given the opportunity reflect, S1 realized the error and fixed it. For this case, Subanji (2015) explains that the student made an error construction of concept which categorized as construction hole error. The reflection S1 does require a long time since he does with caution. Figure 1 shows the subject' process of thinking in solving a limit problem based on the construction of reflective abstractions and the occurrence of reflection by examining the formation of the thinking structure.

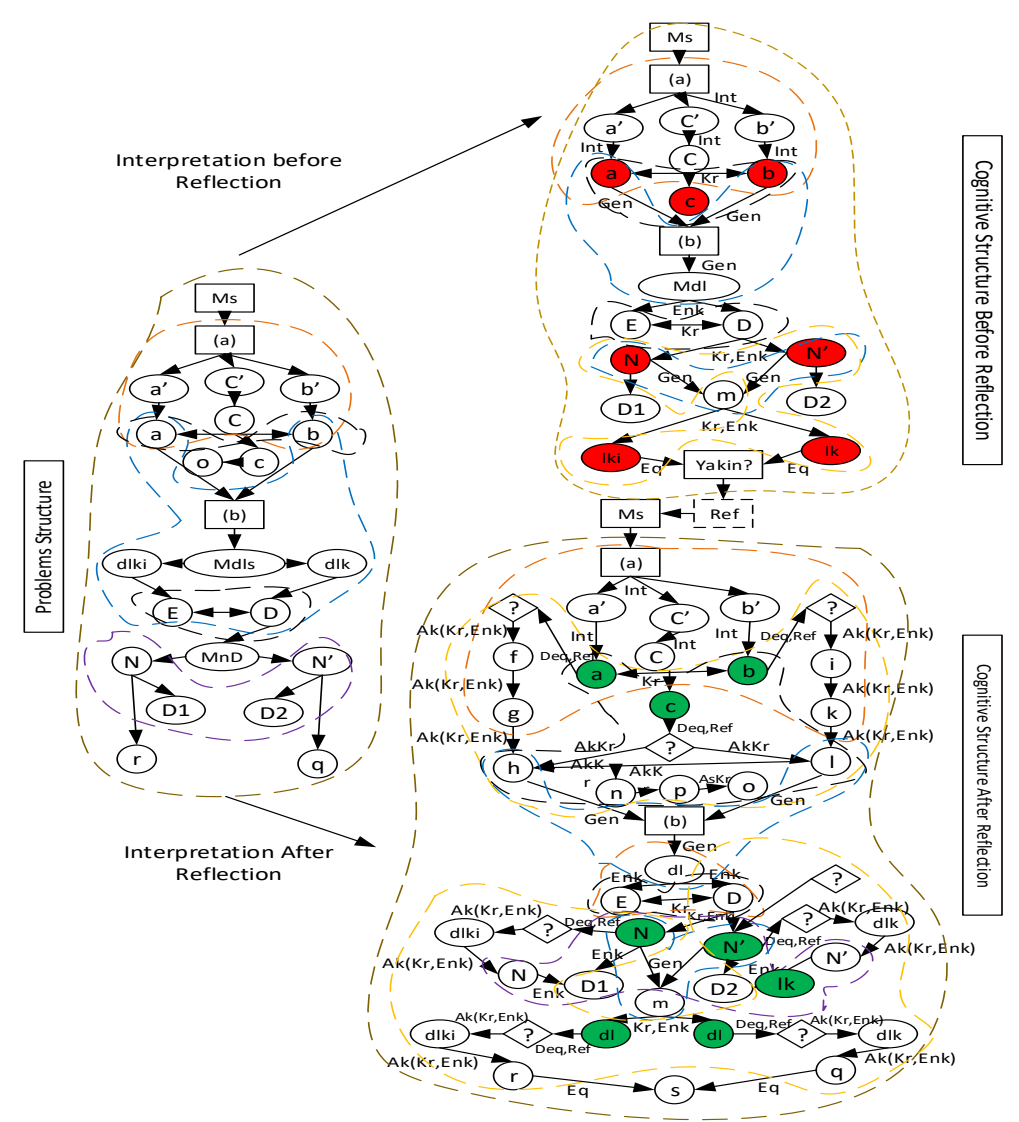

Figure 1. The occurrence of the thinking process from $\mathrm{S} 1$

: Generalization
$\ldots \ldots$


Figure 2 is the subject's path of thinking based on the construction of reflective abstraction in Figure 1.

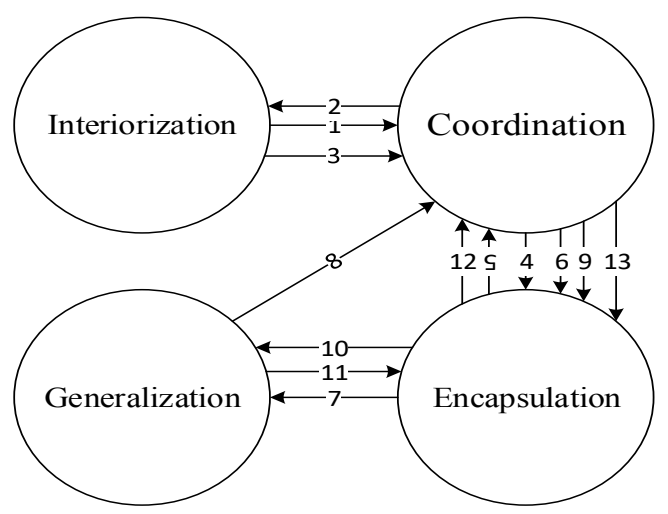

Figure 2. The occurrence of thinking path from S1 in solving limit problems

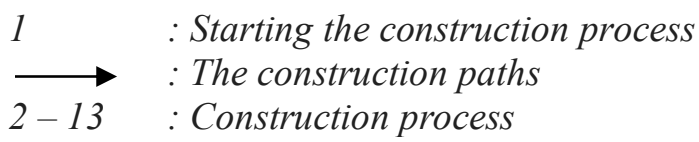

The occurrence of the thinking path of $\mathrm{S} 1$ as in Figure 1 initially does not produce the structure which suits the structure of the problem. Thus, S1 does not get appropriate answers. After answering the problem, S1 does not directly reflect. After being given the opportunity to reflect, S1 accommodates his structure of thinking which resulted in a correct answer. It is in line with what was revealed by Piaget (McCown, 1992) and Sopamena (2009) that accommodation is a process of integrating new stimulus through the formation of a new scheme to adjust to the received stimulus.

When solving the problem (before reflection), Although not optimal, S1 performs the process of interiorization construction, coordination, encapsulation, and generalization. Thus, it does not produce structures that match the structure of the problem. S1 begins solving the problem by reading, observing and identifying the problem. The steps enable $\mathrm{S} 1$ to take action on the issues at hand as he revealed in think aloud as follows.

I will investigate whether the limit $x$ approaches 2 from $f(x)$ exists. If any I will determine its value? Given $f(x)=2 x$ where $x<2$. If $f(2)=2(2)=4$, then for $f(x)=$ 5 where $x=2$ then $f(2)=5$. Because 5 is constant, then for $f(x)=-2 x+8$, where $x$ is greater than 2 then $f(2)=-2(2)+8=4$

At the stage portraited by data from thinking aloud above, the construction process undertaken by $\mathrm{S} 1$ is an interior construction process. S1 constructs internal processes in order to understand the perceived phenomena by inserting the value of $x$ to $f(x)$.

The next step S1 to do is coordinating between the direct substitution with calculating the value of $f(x)$. The process of interiorization S1 can be seen in Figure 3. S1 then coordinates the process of inserting a value of $x$ approaches 2 into the three functions to approach $\lim _{x \rightarrow 2} f(x)$, $\lim _{x \rightarrow 2^{-}} 2 x, \lim _{x \rightarrow 2} 5$, and $\lim _{x \rightarrow 2^{+}}-2 x+8$ along with checking the graph of $f(x)$, to determine whether $\lim _{x \rightarrow 2} f(x)$ exists or not. S1 is confused because of the $f(x)=5$ so that S1 specifies separately $\lim _{x \rightarrow 2^{-}} 2 x=4, \lim _{x \rightarrow 2} 5=5$, and $\lim _{x \rightarrow 2^{+}}-2 x+8=4$ (Figure 3). However, after reflection S1 is 
aware and improves his thinking structure. At this stage, S1 has done coordination process construction followed by encapsulation as shown in his work (Figure 4).

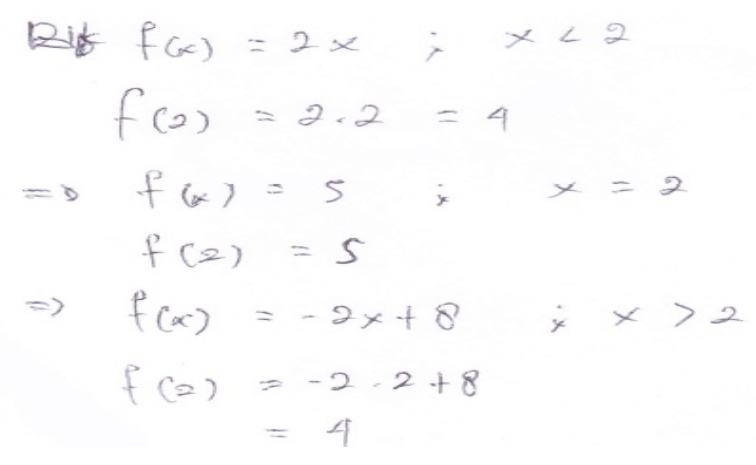

Figure 3. S1's work in finding the limit of multiple functions

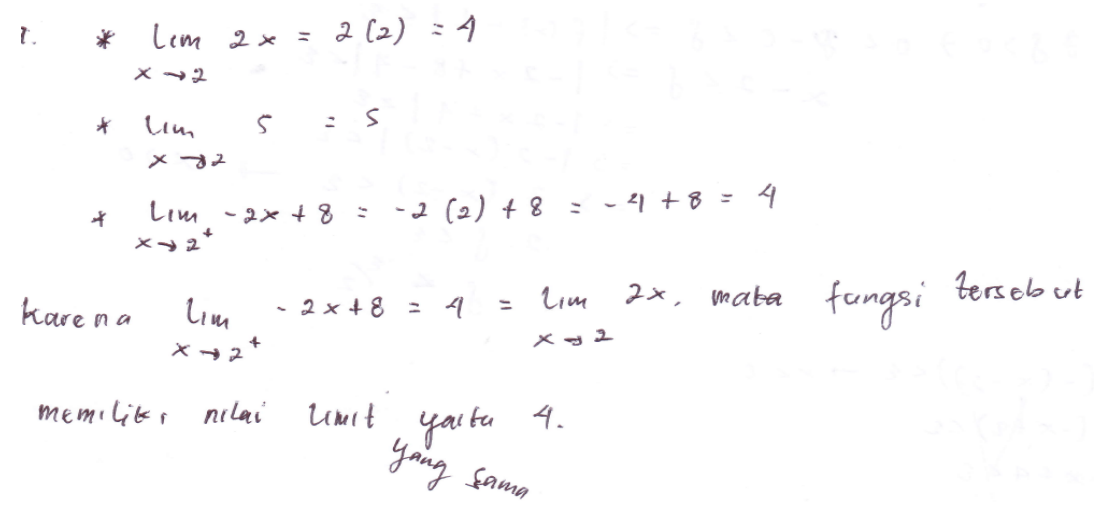

Figure 4. S1's work in investigating the existence of limit after reflection

What $\mathrm{S} 1$ does in Figure 4 is also confirmed through the interview as follows.

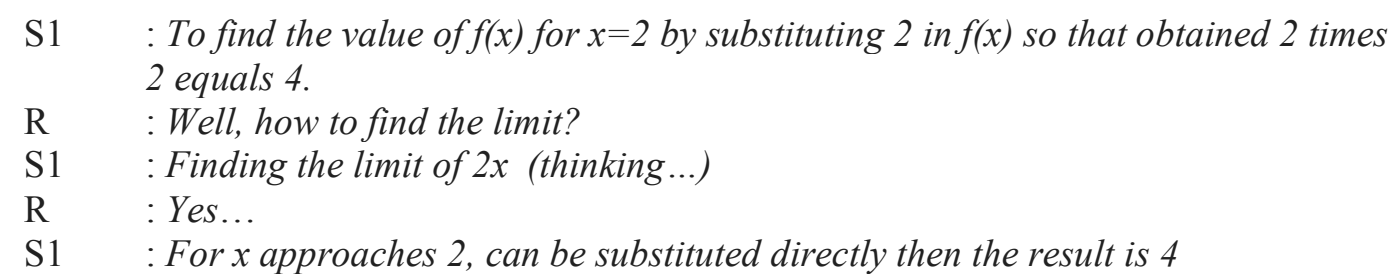

At this stage, S1 performs thinking paths through interiorization - coordination - interiorization - coordination (before reflection) followed by interiorization - coordination - encapsulation (after reflection).

Then S1 thinks to prove that $\lim _{x \rightarrow 2} f(x)=4$. He checks from the left and right limit. At this stage, S1 made a mistake. In this step, S1 begins with a generalization construction process. Figure 5 shows how S1 proves the left limit. At this stage, S1 has done the thinking path generalization - coordination - encapsulation (before reflection) followed by coordination encapsulation - coordination - encapsulation (after reflection) as shown in Figure 2. Figure 6 shows S1' proof after reflection. 
The thinking path with problem-solving processes that require the subject to read the problem and begin solving the problem yields the simple closed path. The paths of thinking the subject goes through likely lead to the correct answer or incorrect answer. The completion of problem-solving to strengthen the concept can use the framework of reflective abstraction construction (interiorization, coordination, encapsulation, and generalization) in Figure 7.

When solving the given problem, the subject with a simple closed path made a mistake. The subject after giving the opportunity to reflect can realize his mistakes and improve the thinking scheme. The subject takes a long time when doing reflection. The thinking structure of the subject with a simple closed path is incomplete and non-optimal (lacking the unilateral components of the rules of limits and the definition of unilateral limitations) which cause errors in the construction process. When the subject is given the opportunity to reflect (subject disequilibration), he reconstructs and reorganizes or accommodates his thinking scheme and improves to obtain the correct answer.

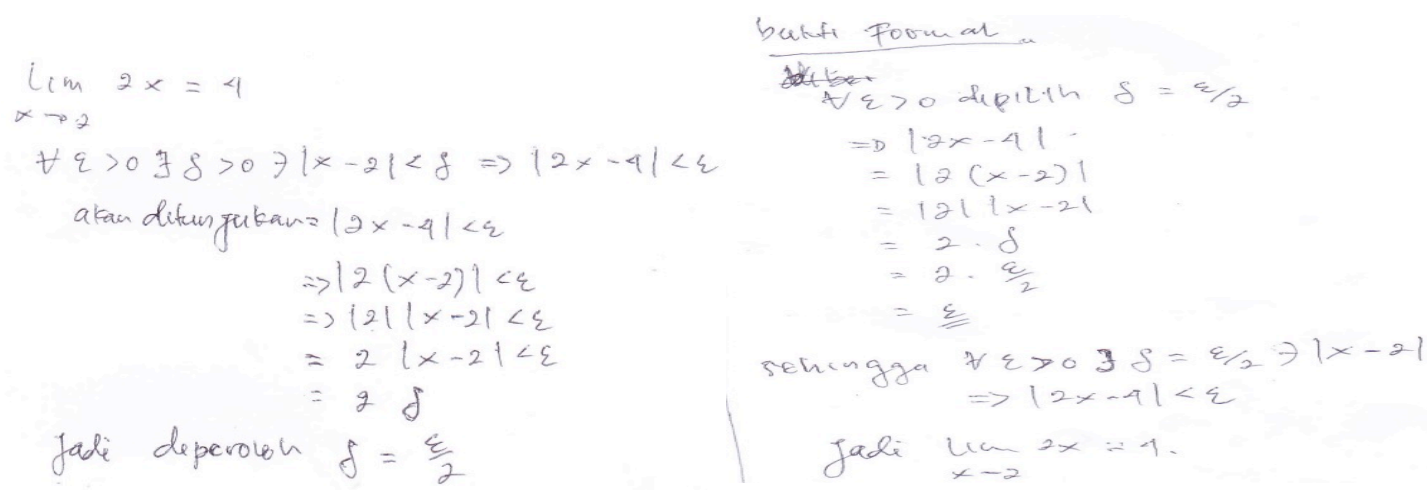

Figure 5. S1's work in proving the left limit

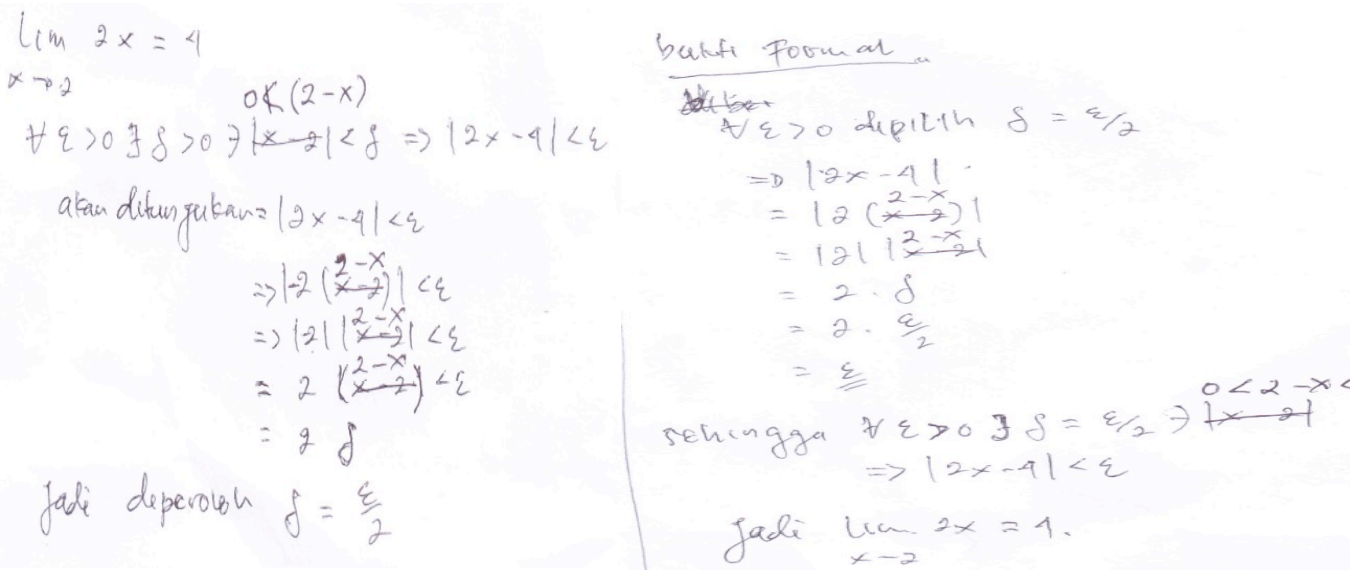

Figure 6. S1's work in proving left limit after reflection

The thinking path of simple closed path occurs back and forth in interiorization construction - coordination - encapsulation - generalization. It is called a simple closed path because when the trajectory arrives at generalization then to coordination $\rightarrow$ encapsulation is different when compared to the general of thinking path of as described by Piaget (Dubinsky, 1991) about the 
types of the construction of reflective abstraction subsequently used by Paschos and Farmaki (2006) as illustrated in Figure 2. The thinking path pursued by the subject which categorized as simple closed thinking path type shown in Figure 7.

The simple closed thinking path (Figure 7) can be explained as follows. When performing the process of finding the limit of functions, subject applies automatic substitution and directly entering the value of $x=2$ with no regard to the given function domain. The reason is to make it easier to determine the limit value (Interiorization construction). At this stage, the subject does not coordinate the process and move to another type of construction.

Then the subject tries back to performs the process of interiorization by creating a geometry representation (graph), performing numerical representation (table) and producing the correct answer that is by coordinating the calculation and graphical or numerical process which then sets the limit value of each function (encapsulation process). The process of interiorization is done in line with what Dubinksy state that interiorization as an internal construction process, namely how to make sense of the observed phenomenon (Paschos \& Farmaki, 2006).

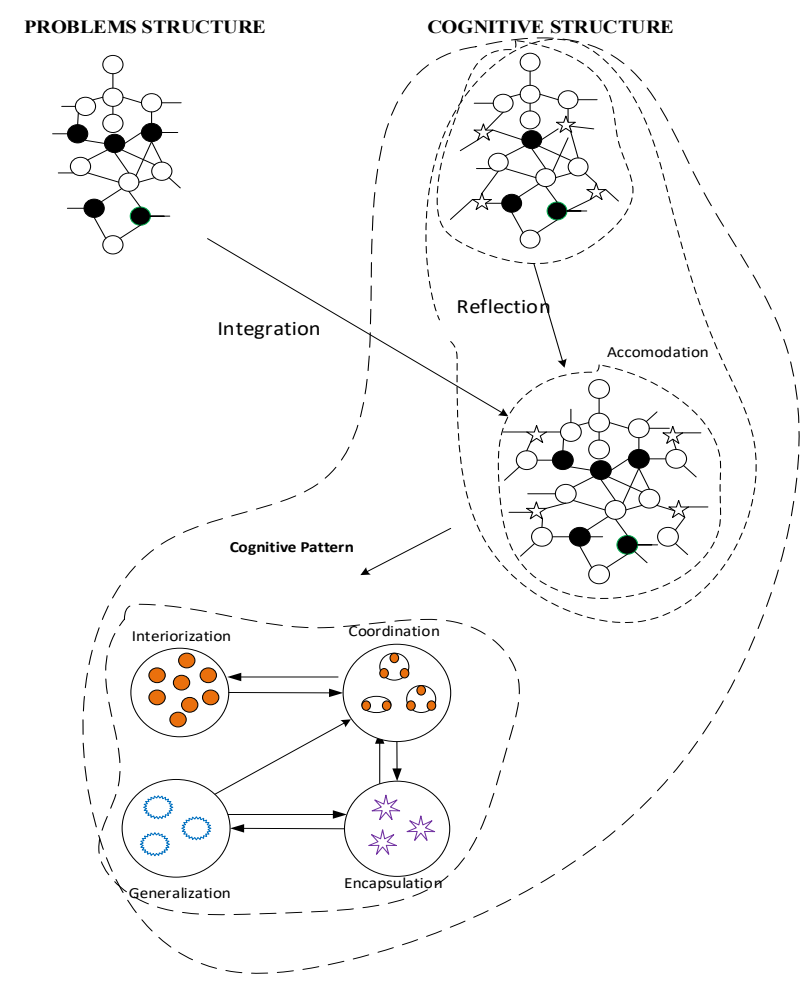

Figure 7. The scheme of simple closed thinking path

The next stage is to determine the value of the limit by considering the relationship between unilateral limits. The construction carried out by the subject is the coordination construction which Dubinsky (1991) call as a composition of two or more to construct a new process. At this stage, the subject is confused (dis-equilibrium) because the multiple functions consist of three discontinuous functions. The subject has only experienced continuous function which has the same limit value. The subject's misconception of the limit results in dis-equilibration which cause the displacement of construction of reflective abstraction. Furthermore, by doing a reflection using the rules of unilateral limitations (left limit is similar to the right limit) finally the subject can accommodate the thinking structure to form a scheme that matches the problem 
structure (equilibration). In this case, the subject performs the switch of coordination construction to another construction of reflective abstraction (generalization process).

\section{Conclusion}

We discuss in this article the path of student's thinking referring to the construction of reflective abstraction which calls as a simple closed path. The path student gets through is interiorization - coordination - encapsulation - generalization then to coordination encapsulation - generalization. We argue that the finding provides essential knowledge for mathematics educators and researchers how undergraduate student solve a mathematics problem. The finding also open-up opportunity for further researches which focus on designing mathematics learning based on the construction of reflective abstraction and a possible way of developing student metacognitive.

\section{References}

Ayers, T., Davis, G., Dubinsky, E., \& Lewin, P. (1988). Computer experiences in learning composition of function. Journal for Research in Mathematics Education, 246-259.

Beth, E. \& Piaget, J. (1966). Mathematical epistemology and psychology. Dordrecht; Springer.

Campbell, R. L. (2001). Reflecting abstraction in context. In R. L. Campbell (Ed), Studies in Reflecting Abstraction (pp. 1-27). East Sussex, England: Psychology Press.

Capetta, R. (2007). Reflective abstraction and the concept of limit: A quasi-experimental study to improve student performance in college calculus and curriculum initiates. Paper presented at the Conference of American Mathematical Association of Two-Year College (AMATYC). Minneapolis.

Cooley, L. (2002). Reflective abstraction and writing in calculus. Journal of Mathematical Behavior, 21(3), 255-282.

Creswell, J. W. (2012). Educational research: Planning, conducting, and evaluating quantitative and qualitative research (4th ed.). Boston, MA: Pearson.

Dubinsky, E. (1991). Reflective abstraction in advanced mathematical thinking. In D. Tall (Ed), Advanced Mathematical Thinking (pp. 95-123). Boston, MA: Kluwer Academic Publishers.

Gallagher.J.M.\& Reid.D.K. (1981). The learning theory of Piaget \& Inhelder. Lincoln: iUniverse, Inc.

Hershkowitz, R., Schwarz, B. B., \& Dreyfus, T. (2001). Abstraction in context: Epistemic actions. Journal for Research in Mathematics Education, 32(2), 195-222.

McCown, R. (1992). Educational psychology and classroom practice: A partnership. New York: Allyn and Bacon

Paschos, T. \& Farmaki.V. (2006). The reflective abstraction in the construction of concept of the definite integral: A case study. International Group for The Psychology of Mathematics Education. Vol.4 (pp. 337-344). PME.

Sopamena, Nusantara, Irawan, \& Sisworo. (2016). Characteristics of thinking processes abstraction reflective of students in solving limits problems. IOSR Journal of Research \& Method in Education (IOSR-JRME), 6 (5), 27-35.

Piaget, J. (2001). Studies in reflecting abstraction (Edited and translated by Robert L. Campbell). East Sussex, England: Psychology Press.

Reiter, B. (2017). Theory and methodology of exploratory social science research. International Journal of Science and Research Methodology, 5(4), 129.

Sopamena, P. (2009). Proses berpikir mahasiswa dalam mengonstruksi bukti keterbagian. Unplished Doctoral thesis. Malang: Univesitas Negeri Malang.

Stebbins, R. A. (2008). Exploratory research. In L. Given (Ed.), The SAGE Encyclopedia of Qualitative Research Methods (pp. 327-329). Sage Thousand Oaks, CA. 
Sopamena, P., Nusantara, T., Irawan, E.B., Sisworo, \& Wahyu, K.

Steffe L.P. (1991). The learning paradox: A plausible counterexample. In Steffe L.P. (Ed), Epistemological Foundations of Mathematical Experience. Recent Research in Psychology. New York: Springer.

Subanji. (2015). Teori kesalahan konstruksi konsep dan pemecahan masalah matematika. Malang: Universitas Negeri Malang Press.

Tall, D. (2013). How humans learn to think mathematically: Exploring the three worlds of mathematics. New York: Cambridge University Press.

Thompson, P. W. (2000). Radical constructivism: Reflections and directions. In L. P. Steffe \& P. W. Thompson (Eds.), Radical constructivism in action: Building on the pioneering work of Ernst von Glasersfeld (pp. 412-448). London: Falmer Press. 